\title{
Microbial turnover of above and belowground litter components in
} shrublands

Marella, Venkata Siva; Hill, Paul; Jones, David; Roberts, Paula

\section{Pedobiologia}

DOI:

10.1016/j.pedobi.2016.07.001

Published: 01/07/2016

Peer reviewed version

Cyswllt i'r cyhoeddiad / Link to publication

Dyfyniad o'r fersiwn a gyhoeddwyd / Citation for published version (APA):

Marella, V. S., Hill, P., Jones, D., \& Roberts, P. (2016). Microbial turnover of above and belowground litter components in shrublands. Pedobiologia, 59(4), 229-232.

https://doi.org/10.1016/j.pedobi.2016.07.001

\footnotetext{
Hawliau Cyffredinol / General rights

Copyright and moral rights for the publications made accessible in the public portal are retained by the authors and/or other copyright owners and it is a condition of accessing publications that users recognise and abide by the legal requirements associated with these rights.

- Users may download and print one copy of any publication from the public portal for the purpose of private study or research.

- You may not further distribute the material or use it for any profit-making activity or commercial gain

- You may freely distribute the URL identifying the publication in the public portal?
}

Take down policy

If you believe that this document breaches copyright please contact us providing details, and we will remove access to the work immediately and investigate your claim. 
1 Title: Microbial turnover of above and belowground litter components in

2 shrublands

3 Authors: Venkata S. S. R. Marella, Paul W. Hill, Davey L. Jones, Paula Roberts*

4 Address: School of Environment, Natural Resources and Geography, Bangor

5 University, Gwynedd, LL57 2UW, UK.

6 *Corresponding Author: E-mail:p.roberts@bangor.ac.uk

7 Author contributions: All authors contributed equally to the research and manuscript 8

9

10

11

12

13

14

15

16

17

18

19

20

21 


\section{Abstract}

Shrublands cover a large proportion of the world's land surface, yet they remain poorly studied in comparison to other ecosystems. Within shrublands, soil organic matter (SOM) is replenished from inputs of both above- and below-ground plant litter, however, their relative importance depends on their respective turnover rates. To critically address this, we measured the biodegradation rates of the soluble and insoluble components of ${ }^{14} \mathrm{C}$-labelled above- and below-ground plant litter in soil. During the 150 day incubation, the amount of plant-derived soluble-C lost as ${ }^{14} \mathrm{CO}_{2}$ was similar for the different plant parts being $64.7 \pm 2.3 \%$ for roots, $72.1 \pm 7.4 \%$ for stems, and $72.4 \pm 1.8 \%$ for leaves. In comparison, the turnover of the insoluble fraction was much slower. However, again little difference in mineralisation was seen for the different plant parts with the total losses being $21.1 \pm 0.9 \%$ for roots, $19.5 \pm 1.6 \%$ for stems, and $19.6 \pm 1 \%$ for leaves. A double exponential first order kinetic model fitted well to the experimental data. It also allowed the partitioning of $\mathrm{C}$ between microbial anabolic and catabolic processes for the soluble $\mathrm{C}$ component. Using this model, we deduced that the soluble fraction turns over $c a .40$ times annually, whereas it takes $c a$. 2.5 years to turnover the insoluble fraction. For the soluble plant component, the overall microbial carbon use efficiency (CUE) was estimated to be greater for root-derived C in comparison to that derived from aboveground (no difference was observed for the insoluble component). From this, we tentatively suggest that $\mathrm{C}$ sourced from belowground plant components may persist longer in soil than $\mathrm{C}$ derived from aboveground plant components.

Key words: belowground carbon storage, mineralisation, nutrient cycling, litter decomposition, root turnover 
Soil organic matter (SOM) represents a major store of terrestrial carbon $(\mathrm{C})$ (Schlesinger, 1997) and its turnover and replenishment represents a critical component of the global C cycle. SOM is primarily derived from the continual input of above- and

51 below-ground plant components, however, their relative importance, particularly in 52 shrubland ecosystems, remains poorly understood (Vogt et al., 1986). Earlier studies have suggested that plant roots contribute a larger proportion of $\mathrm{C}$ to soil organic carbon (SOC) than plant shoots, due to their greater chemical recalcitrance in relation to microbial enzymatic breakdown (Broadbent and Nakashima, 1974; Jane et al., 2007). In contrast, within some agroecosystems, significant contributions by crop shoots have also been observed (Barber, 1979).

The input of organic matter to the soil can be broadly classified into two pools (van Hees et al., 2005). The first pool is described as the dissolved organic C component that includes low molecular weight, highly bioavailable compounds such as organic acids, peptides, amino acids, mono- and oligo-saccharides, amino sugars, phenolics and siderophores (McKeague et al., 1986). The second pool consists of plant polymers such as cellulose, hemicellulose, lignin and some proteins, which are relatively resistant to microbial attack (Kalbitz et al., 2000). These two pools can have vastly different C:N:P ratios which may subsequently influence their rate of processing and also microbial carbon use efficiency (CUE; Schmidt et al., 2011).

Numerous studies have described the mineralisation of individual low molecular weight compounds (Glanville et al., 2012), plant material (Simfukwe et al., 2011) and have measured the subsequent rates of ${ }^{14} \mathrm{CO}_{2}$ evolution and/or microbial incorporation.

70 These studies have enhanced our understanding of the ${ }^{14} \mathrm{C}$ mineralisation process of 71 single or occasionally combinations of simple $\mathrm{C}$ compounds by the microbial 
community. However, plant material consists of vast range of compounds (Buckingham, 1993) and the mineralisation capacity of microorganisms to act upon more complex suite of substrates provides a more representative estimate of the potential for $\mathrm{C}$ storage in soil. Therefore, the aim of this study was to assess the microbial turnover of the soluble and insoluble fractions of above- and below-ground plant components (root, stem, leaf) from a common shrubland plant to assess their persistence in the soil under laboratory conditions.

Soil was obtained from the Henfaes experimental station located in Abergwyngregyn, Gwynedd, North Wales $\left(53^{\circ} 14^{\prime} \mathrm{N}, 4^{\circ} 01^{\prime} \mathrm{W}\right) \mathrm{UK}$. The sandy clay loam textured soil is classified as a Eutric Cambisol (FAO) or Dystric Eutrudepts (US Soil Taxonomy) (see $\mathrm{SM}_{1}$ and Table $\mathrm{S}_{1}$ ). Cistus monspeliensis $\mathrm{L}$. plants were grown in a hydroponic system consisting of 50\% strength Long Ashton nutrient solution under laboratory conditions. Plants were labelled with ${ }^{14} \mathrm{C}$ twice, 3 days apart for $5 \mathrm{~h}$ each time to get sufficient translocation of ${ }^{14} \mathrm{C}$ to all plant components (see $\mathrm{SM}_{2}$ ). Immediately after the second labelling, the plant components were separated into leaves, stem, and roots and air-dried. The dried plant parts were finely ground using a ball mill and stored in $50 \mathrm{ml}$ polypropylene tubes at $20^{\circ} \mathrm{C}$ for further analysis. The distribution of ${ }^{14} \mathrm{C}$ label among soluble and structural fractions of plant material was determined by performing a sequential chemical extraction. These results were tested in parallel with unlabelled plants, using an automated fibre analyser (see $\mathrm{SM}_{3}$ ). The soluble and insoluble fraction from each of the three plant components were separated using a hot water extract (see $\mathrm{SM}_{4}$ ) and amended to field-moist soil contained in $50 \mathrm{~cm}^{3}$ polypropylene tubes. The mineralisation of the ${ }^{14} \mathrm{C}$-labelled components was studied for 150 days and values were expressed as a percentage of the initial amount of ${ }^{14} \mathrm{C}$ applied to the soil (see $\mathrm{SM}_{5}$ ). Similar extraction process was conducted with unlabelled 
plant components and the soluble fraction from each component was analysed for distribution of low molecular weight $(\leq 300 \mathrm{Da})$ compounds using MALDI-TOF mass spectrometry (Bruker Reflex IV) with $\mathrm{TiO}_{2}$ as a matrix. At the end of the incubation period, the amount of soluble ${ }^{14} \mathrm{C}$ remaining in the soil either as unaltered plant material or fixed in the microbial biomass was determined by extracting the soil in $0.5 \mathrm{M} \mathrm{K}_{2} \mathrm{SO}_{4}$ (see $\mathrm{SM}_{6}$ ). A double exponential first order decay model was then fitted to the experimental data (Glanville et al., 2016). Substrate-C pool distribution within the microbial community, decay constants, CUE and half-lives (Newton-Raphson iteration method) (Oburger and Jones, 2009) were calculated (see $\mathrm{SM}_{7}$ ). The data was analysed by one-way ANOVA with Post-Hoc least significant difference test using SPSSv20.0 (SPSS Inc., Chicago, IL) using $P<0.05$ as an indication of statistical significance. Following the labelling process, the distribution of ${ }^{14} \mathrm{C}$ into soluble and structural fractions of the different plant components was broadly similar to the total amount of unlabelled ${ }^{12} \mathrm{C}$ in each chemical fraction, although the data for stems is not available (Table $S_{2}$ ). This indicates a fairly uniform dilution of the ${ }^{14} \mathrm{C}$ isotope within the plant. The addition of ${ }^{14} \mathrm{C}$-labelled soluble and insoluble fractions to soil caused an initial rapid phase of ${ }^{14} \mathrm{CO}_{2}$ evolution followed by a secondary slower phase, irrespective of plant tissue type (Fig. 1). The overall amount of ${ }^{14} \mathrm{C}$ mineralisation in soils amended with soluble fractions was substantially higher compared to the values obtained for the insoluble fractions $(P<0.001)$. This was presumably due to the presence of more labile low molecular weight compounds in the soluble fractions. Conversely, insoluble fractions broadly consist of structural polymers which require enzymatic depolymerisation to promote solubilisation prior to uptake and assimilation by the microbial community (van Hees et al., 2005). Among the soluble fractions, rootderived ${ }^{14} \mathrm{C}$ showed the fastest mineralisation rate followed by stem and leaf ${ }^{14} \mathrm{C}$ during 
the first hour, presumably because of relatively higher quantities of low molecular weight compounds which exist in roots (Figs. $\mathrm{S}_{1}$ and $\mathrm{S}_{2}$ ). After $24 \mathrm{~h}$, the amount of ${ }^{14} \mathrm{C}$ mineralisation of the root soluble fraction $(19.7 \pm 0.4 \%)$ was substantially higher than for the stems $(8.7 \pm 0.3 \%)$ and leaves $(5.7 \pm 0.3 \%)$. Similarly, among the insoluble fractions, the root-derived ${ }^{14} \mathrm{C}$ fraction had the highest initial mineralization rate $(0.62$ $\pm 0.2 \%)$ within $24 \mathrm{~h}$, followed by the stems $(0.43 \pm 0.02 \%)$ and leaves $(0.26 \pm 0.01 \%)$. However, at the end of 150 days, the pattern had changed with $64.7 \% \pm 2.3,72.1 \pm$ $7.4 \%$, and $72.4 \pm 1.8 \%$ of the soluble fraction lost for the root, stem and leaf-derived

${ }^{14} \mathrm{C}$, respectively. In contrast, for the three insoluble fractions the amount recovered as ${ }^{14} \mathrm{CO}_{2}$ after $150 \mathrm{~d}$ was very similar, being $21.1 \pm 0.9 \%, 19.5 \pm 1.6 \%$, and $19.6 \pm 1 \%$ of the total ${ }^{14} \mathrm{C}$ added for the root, stem and leaves respectively.

The amount of ${ }^{14} \mathrm{C}$ allocated to the rapid mineralisation pool $\left(a_{1}\right)$ and corresponding decay constant values $\left(k_{1}\right)$ were much higher for soluble fractions than insoluble fractions (Table 1), presumably due to their rapid assimilation by microbial biomass (Boddy et al., 2007). This is supported by the lack of soluble- ${ }^{14} \mathrm{C}$ recovered from the soil after $150 \mathrm{~d}$ (Fig. 2). The half-life periods calculated from $k_{1}$ for the insoluble fractions were 3-5 fold longer than that of the soluble fraction. However, the $k_{2}$ values were very low (100-200 times lower than the $k_{1}$ values) for both soluble and insoluble fractions and were significantly different. Using the Newton-Raphson iteration method, the combined half-life period for both pools together $\left(a_{1}+a_{2}\right)$ was $c a$. 9 and $930 \mathrm{~d}$ for the soluble and insoluble fractions respectively (Oburger and Jones, 2009). Thus, soluble fractions turnover $c a .40$ times annually, whereas insoluble fractions take $c a .2 .5$ years to turnover.

It was interesting to note that approximately $20 \%$ more soluble $\mathrm{C}$ derived from the aboveground plant components (leaf and stem) was allocated to microbial catabolic 
147 C pools (pool $a_{1}$ ) than soluble $\mathrm{C}$ derived from the belowground component (despite 148 having an initial slower ${ }^{14} \mathrm{C}$ mineralisation rate). Conversely, more root-derived soluble

$149{ }^{14} \mathrm{C}$ was allocated to anabolic microbial processes (pool $a_{2}$ ) thus resulting in a higher 150 CUE for the below-ground soluble component (Glanville et al., 2016). Hence, microbes 151 have shown more efficient usage of root soluble ${ }^{14} \mathrm{C}$ compared to leaf and stem which 152 could be major driver for ecosystem C storage potential (Sinsabaugh et al., 2013). Thus, 153 we tentatively suggest that $\mathrm{C}$ sourced from belowground plant components persists 154 longer than the above ground plant components in soil. However, overall contributions 155 can only be calculated once the total flux of each component into the ecosystem is 156 known. In addition, the amount of $\mathrm{C}$ associated with mycorrhizal turnover and root 157 exudation would be needed to complete the budget. Nevertheless, the results obtained 158 here highlight the importance of roots in soil $\mathrm{C}$ storage especially as plants in most 159 shrublands heavily invest in belowground biomass in the form of a deeper root system 160 (Meyer, 2011). Results also support suggestions that increased allocation of $\mathrm{C}$ to roots 161 under elevated atmospheric $\mathrm{CO}_{2}$ may partially mitigate atmospheric $\mathrm{CO}_{2}$ rise by 162 increasing soil C storage (Madhu and Hatfield, 2013).

163 In conclusion, this study has clearly demonstrated the faster mineralisation of 164 soluble fractions compared to the insoluble fractions. Additionally, modelling of the C 165 pools tentatively suggests the longer persistence of belowground components in soil 166 relative to shoots and leaves.

167

168 Acknowledgements

169 We would like to thank Barry Grail for his assistance in MALDI-TOF MS 170 analysis, Helen Glanville for her helpful advice ${ }^{14} \mathrm{C}$ modelling and Jonathan Roberts 171 for technical support. 


\section{References}

173 Buckingham, J., 1993. Dictionary of Natural Products. Chapman \& Hall, London.

174 Barber, S.A., 1979. Corn residue management and soil organic matter. Agronomy Journal, 71: 625-627.

Boddy, E., Hill, P.W., Farrar, J., Jones, D.L., 2007. Fast turnover low molecular weight components of the dissolved organic carbon pool of temperate grassland field soil. Soil Biology \& Biochemistry, 39: 827-835.

Broadbent, F.E., Nakashima, T., 1974. Mineralisation of carbon and nitrogen in soil amended with carbon-13 and nitrogen-15 labelled plant material. Soil Science Society of America Proceedings, 38: 313-315.

Glanville, H., Rousk, J., Golyshin, P., Jones, D.L., 2012. Mineralisation of low molecular weight carbon substrates in soil solution under laboratory and field conditions. Soil Biology \& Biochemistry 48: 88-95.

Glanville, H.C., Hill, P.W., Schnepf, A., Oburger, E., Jones, D.L., 2016. Combined use of empirical data and mathematical modelling to better estimate the microbial turnover of isotopically labelled carbon substrates in soil. Soil Biology \& Biochemistry, 94: 154-168.

Jane, M.F.J., Nancy, W. B., Sharon, L.W., 2007. Chemical composition of crop biomass impacts its decomposition. Soil Science Society of America Journal, 71: $155-162$.

Kalbitz, k., Solinger, S., Park, J.H., Michalzik, B., Matzner, E., 2000. Controls on the dynamics of dissolved organic matter in soils: a review. Soil Science 165, 277304.

Madhu, M., Hatfield, J.L., 2013. Dynamics of plant root growth under increased atmospheric carbon dioxide. Agronomy Journal, 105: 657-669. 
Mc Keague, J. A., Chesire, M.V., Andreux, F., Berthelin, J., 1986. Organomineral complexes in relation to paedogenesis, in: Huang PM, Schnitzer, M (Eds). Interactions of Soil Minerals with Natural Organics and Microbes. Soil Science Society of America, Madison WI, pp. 549-592.

Meyer, S.E., 2011. Is climate change mitigation the best use of desert shrublands? Natural Resource and Environmental Issues, 17: Article 2.

Oburger, E., Jones, D.L., 2009. Substrate mineralisation studies in the laboratory show different microbial $\mathrm{C}$ partitioning dynamics than in the field. Soil Biology \& Biochemistry, 41: 1951-1956.

Schlesinger, W., 1997. Biogeochemistry: an Analysis of Global Change. Academic Press, $2^{\text {nd }}$ edition.

Schmidt, M. W.I., Torn, M.S., Abiven, S., Dittmar, T., Guggenberger, G., Janssens, I.A., Kleber, M., Kögel-knabner, I., Lehmann, J., Manning, D.A.C., Nannipieri. P., Rasse, D.P., Weiner, S., Trumbore, S.E., 2011. Persistence of soil organic matter as an ecosystem property. Nature, 478: 49-56.

Simfukwe, P., Hill, P. W., Emmett, B. A., Jones, D. L., 2011. Soil classification provides a poor indicator of carbon turnover rates in soil. Soil Biology \& Biochemistry, 43: 1688-1696.

Sinsabaugh, R.L., Manzoni, S., Moorhead, D.L., Richter, A., 2013. Carbon use efficiency of microbial communities: stoichiometry, methodology and modelling. Ecology Letters, 16: 930-939.

van Hees, P.A.W., Jones, D.L., Finlay, R., Godbold, D., Lundström, U.S., 2005. The carbon we do not see - the impact of low molecular weight compounds on carbon dynamics and respiration in forest soils: a review. Soil Biology \& Biochemistry, 37: 1-13. 
222 Vogt, K. A., Grier, C. C., Vogt, D. J., 1986. Production, turnover, and nutrient dynamics of above- and belowground detritus of world forests. Advances in Ecological Research, 15: 303-377.

225 